\title{
Petrography and Provenance of Sandstones from the Aghajari Formation, Folded Zagros Zone, Southwestern Iran
}

\author{
Mohammad Sahraeyan $^{1}$ and Mohammad Bahrami ${ }^{2}$ \\ ${ }^{1}$ Department of geology, Islamic azad University, Khorasgan (Esfahan) Branch, \\ Esfahan, Iran \\ e-mail: M.Sahraeyan@yahoo.com \\ ${ }^{2}$ Department of geology, Islamic azad University, Fars Science and Research \\ Branch, Shiraz, Iran \\ e-mail: Mbahrami1329@yahoo.com
}

\begin{abstract}
The Late Miocene- Pliocene Aghajari Formation is exposed throughout the Folded Zagros Zone and consists of fluvial sediments. Detailed petrographic studies of sandstone samples from the Aghajari formation contain abundant quartz and lithic grains with subordinate feldspars, accessory amounts of micas. The feldspar content mostly ranges from 0 to $5 \%$. The abundance of lithic grains shows a wide range of variation (5.9 to $69.8 \%$ ). Although the lithics are mainly sedimentary, but fragments of metamorphic rocks are observed. Micas, including both muscovite and biotite, are generally less than $5 \%$ of the total detrital grains. On the basis of the framework composition (point counting), the sandstones are classified as lithic arenite and sublitharenite. The modal analysis data of 75 collected (medium size and well sorted) samples, imply a recycled orogen (quartzose and transitional recycled) tectonic provenance. Moreover, petrographic point count data indicate the sources of quartzs are low-grade and middle to high-grade metamorphic rocks. Also quartz-rich (sedimentary) and granitic/gneissic are parent rocks for the Aghajari Formation sandstones.
\end{abstract}

Keywords: Aghajari Formation, Folded Zagros Zone, Petrography, Provenance. 


\section{Introduction}

Petrography and heavy mineral suites of sandstone provide information about the nature of source rocks, the uplift history and evolution of orogenic belts. However, at the same time, weathering conditions in the source area also play an important role in controlling sediments composition [1].

The determination of the provenance of sandstones using the framework mineral composition (detrital modes) was first proposed by Crook [2] and has since undergone considerable refinement (e.g., $[3,4,5,6])$. The main assumption behind sandstone provenance studies is that different tectonic settings contain their own rock types, which when eroded, produce sandstones with specific compositional ranges (e.g., [3, 4, 7]).

Basu et al. [8] and Tortosa et al. [9] used the frequency of different types of quartz grains to infer the type of source rocks. Thus, simple petrographic descriptions of different quartz constituents can be utilized for this purpose $[10,11,12]$.

\section{Regional Geology}

The geological evidence suggests that the Zagros region was part of a passive continental margin, which subsequently underwent rifting during the PermoTriassic and collision during the Late Tertiary [13, 14, 15]. In fact, the Zagros fold - thrust belt lies on the northeastern margin of the Arabian plate and has been divided into NW- SE trending structural zones (imbricated and simply folded belt) parallel to the plate margin separated by major fault zones such as the High Zagros and mountain front faults (Fig. 1A). In addition to the tectonic divisions parallel to the mountain belt, the belt has also been divided laterally to the Lurestan, Dezful embayment and Fars regions from northwest to southeast.

The Aghajari Formation is present throughout the Zagros Basin, but, because of its gradual subsidence during deposition, it is best developed in Dezful Embayment (about 3000 meters) and probably increases in the synclines of this region. The Aghajari Formation was studied in detail and formally defined by James and Wynd [16]. Aghajari Formation in its type section, consists of 2966 meters alternation layers of brown to gray calcareous sandstones and red marls with gypsum interlayers, and red siltstones [17]. Aghajari Formation in Zagros Zone is characterized with two lithofacies groups that each develops in internal Fars and northwestern of Dezful Embayment. The first is mostly continental clastic sediments (i.e. mudstone, sandstone, and conglomerate), but the second one, that spreads in coastal Fars, has a marine characteristics (i.e. marl with gypsum inter-layers). Deposition of the Aghajari Formation took place during the Late Miocene- Pliocene [18], but it doesn't have unity in age and becomes younger from northwestern to south-eastern and from northeastern to southwestern. In the type section, the lower contact with Mishan Formation is dominantly gradual and sometimes abrupt. The upper contact with Bakhtyari 
Formation is sometimes gradual and conformable and occasionally abrupt and unconformable. In the study area, the lower contact with Razak Formation and the upper contact with Bakhtyari Formation are gradual (Fig. 1B).

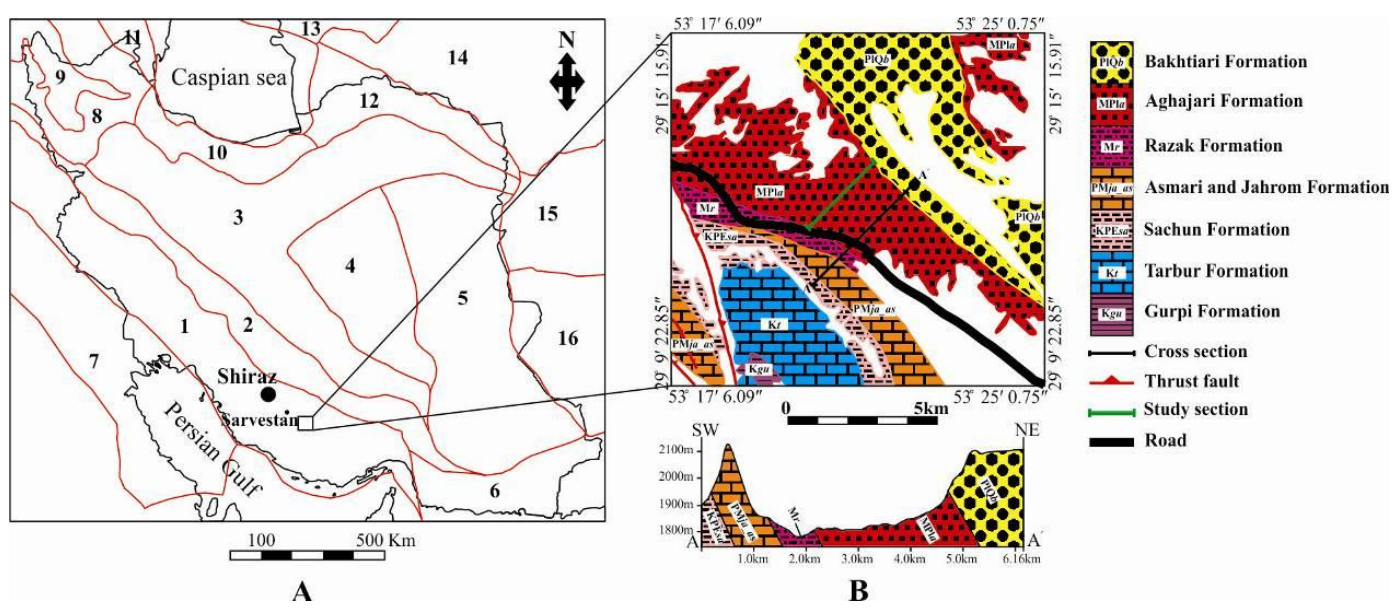

Fig. 1- A: General map of geological states of Iran, the study area is located in Folded Zagros Zone (after ${ }^{[19]}$ ); B: Geological map of study area (after ${ }^{[20]}$ ).

Aghajri Formation is equivalent to Fat'ha and Injana Formations in Iraq, Upper Fars and Lower Fars in Syria and Kuwait, and Kial and Jabal Kibrit Formations in Saudi Arabia [21]. The Aghajari Formation includes Lahbari Clastic Member at its upper part. The above mentioned studies focused primarily on oil producing areas (southwestern of Iran). Sedimentology, sedimentary environment, and morphotectonical evolution of Aghajari and Bakhtyari Formations are tought out by Bahrami [22]. A detailed account of the lithology, sedimentary facies, and sedimentary environments of Aghajari Formation is reported by Bahrami [23] and Sahraeyan et al. [24] as fluvial deposits.

No detailed studies on the petrography of this formation have been carried out. The purpose of the present study is to use a petrographical approach to decipher the sedimentary provenance and source rock of the Aghajari Formation sandstones from the Folded Zagros Zone. This is the first study that presents these data of Aghajari Formation sediments.

\section{Materials and Methods}

Sandstone samples from the silisiclastic deposits of the Aghajari Formation (Late Miocene- Pliocene) were studied in the present work. 75 sandstone samples were collected from Aghajari Formation sandstones.

Framework mineral composition (modal analysis) was quantified using the pointcounting method of Gazzi-Dickinson as described by Ingersoll et al. [25]. In the 
Gazzi-Dickinson method [25], minerals $>0.625 \mathrm{~mm}$ within lithoclasts are counted acording to the mineral type (phaneritic grains: crystal size exceeding $0.0625 \mathrm{~mm}$; aphanitic grains: crystal size less than $0.0625 \mathrm{~mm}$ ). The grid spacing used in point counting exceeded the grain size so as to avoid individual grains being counted more than once. In order to reconstruct the original detrital composition of the sandstone, the effects of diagenesis such as calcitization, zeolitization, and albitization of feldspars were taken into consideration as much as possible during counting. Framework grains were counted for 300 to 350 counts per thin section; recalculated modal analysis data from point counting of the framework grains are listed in Table 1.

Table 1- Detrital modes of sandstone samples from the Aghajari Formation,

Folded Zagros Zone, Iran.

\begin{tabular}{ccccccccccc}
\hline Sample & Qt & Lt & F & Qu & Qnu & Qp & Ls & Lv & Lm & Ch \\
\hline AJ-2 & 52.3 & 46.4 & 1.3 & 39.7 & 8.4 & 4.2 & 40.7 & 0 & 3.5 & 2.2 \\
AJ-4 & 30.8 & 69.2 & 0 & 19.3 & 6 & 5.5 & 64.3 & 0 & 1 & 3.9 \\
AJ-5 & 55.6 & 43.6 & 0.8 & 40.5 & 11.2 & 3.9 & 36.9 & 0 & 2.1 & 4.6 \\
AJ-7 & 29.6 & 69.3 & 1.1 & 16.8 & 9.4 & 3.4 & 63.1 & 0 & 2.2 & 4 \\
AJ-11 & 58.2 & 40.4 & 1.4 & 30 & 20.1 & 8.1 & 35.2 & 0 & 1.5 & 3.7 \\
AJ-13 & 53.1 & 45.8 & 1.1 & 34.5 & 12.6 & 6 & 37.6 & 0 & 3 & 5.2 \\
AJ-15 & 53 & 46.3 & 0.7 & 29 & 19.9 & 4.1 & 39.5 & 0 & 0 & 6.8 \\
AJ-18 & 57.5 & 42 & 0.5 & 36.2 & 15.4 & 5.9 & 36 & 0 & 0.5 & 5.5 \\
AJ-20 & 42.2 & 56.9 & 0.9 & 19.8 & 18.1 & 4.3 & 51.5 & 0 & 0.9 & 4.5 \\
AJ-22 & 41.6 & 57.9 & 0.5 & 22.6 & 14.7 & 4.3 & 50.3 & 0 & 3 & 4.6 \\
AJ-24 & 56.5 & 41 & 2.5 & 32.3 & 20 & 4.2 & 32.8 & 0 & 2.6 & 5.6 \\
AJ-26 & 62 & 35.8 & 2.2 & 42.6 & 15 & 4.4 & 30.2 & 0 & 1.7 & 3.9 \\
AJ-28 & 45.1 & 53 & 1.9 & 29.3 & 12.6 & 3.2 & 44.7 & 0 & 1.3 & 7 \\
AJ-30 & 46 & 53.3 & 0.7 & 30.8 & 13.3 & 1.9 & 45.9 & 0 & 1.2 & 6.2 \\
AJ-34 & 59.1 & 38.9 & 2 & 45 & 8.2 & 5.9 & 32.6 & 0 & 1 & 5.3 \\
AJ-36 & 64.3 & 33.3 & 2.4 & 47.5 & 11.2 & 5.6 & 30 & 0 & 0.4 & 2.9 \\
AJ-38 & 44.3 & 54.2 & 1.5 & 26.4 & 12.6 & 5.3 & 47.2 & 0 & 2.2 & 4.8 \\
AJ-40 & 50.3 & 47.3 & 2.4 & 36.9 & 8.6 & 4.8 & 42.7 & 0 & 1 & 3.6 \\
AJ-41 & 51.7 & 46.8 & 1.5 & 32.9 & 13.6 & 5.2 & 40 & 0 & 1.4 & 5.4 \\
AJ-43a & 63.1 & 34.4 & 2.5 & 41.2 & 18.8 & 3.1 & 27.5 & 0 & 1.7 & 5.2 \\
AJ-43b & 66.9 & 31 & 2.1 & 36.7 & 25.9 & 4.3 & 23.5 & 0 & 1.2 & 6.3 \\
AJ-45 & 33.9 & 65.1 & 1 & 23.3 & 7.6 & 3 & 55.9 & 0 & 3.2 & 6 \\
AJ-47 & 72.3 & 26.1 & 1.6 & 46 & 22.2 & 4.1 & 23 & 0 & 0.5 & 2.6 \\
AJ-49a & 92.4 & 7.6 & 0 & 62.1 & 25.6 & 4.7 & 5.1 & 0 & 0 & 2.5 \\
AJ-49b & 92 & 5.9 & 2.1 & 62.2 & 25.2 & 4.6 & 5.9 & 0 & 0 & 0 \\
AJ-56 & 28.5 & 67.6 & 3.9 & 15.2 & 10.6 & 2.7 & 60.4 & 0 & 2.3 & 4.9 \\
AJ-58 & 46.5 & 51.4 & 2.1 & 28.2 & 17.6 & 0.7 & 46.1 & 0 & 1.2 & 4.1 \\
AJ-59 & 73.2 & 26.8 & 0 & 56.7 & 13.8 & 2.7 & 23.7 & 0 & 0 & 3.1 \\
\hline
\end{tabular}




\begin{tabular}{|c|c|c|c|c|c|c|c|c|c|c|}
\hline AJ-62 & 31.1 & 64.8 & 4.1 & 14.5 & 13.2 & 3.4 & 59.8 & 0 & 2.4 & 2.6 \\
\hline AJ-64 & 35 & 63.5 & 1.5 & 27.8 & 5.2 & 2 & 57.1 & 0 & 0.5 & 5.9 \\
\hline AJ-66 & 50 & 47.7 & 2.3 & 33.2 & 14 & 2.8 & 43.2 & 0 & 0.8 & 3.7 \\
\hline AJ-68 & 51.8 & 48.2 & 0 & 24.1 & 25.1 & 2.6 & 42.3 & 0 & 2 & 3.9 \\
\hline AJ-70 & 38.7 & 61.3 & 0 & 16.2 & 16.5 & 6 & 52.4 & 0 & 3.8 & 5.1 \\
\hline AJ-72 & 50.5 & 48.8 & 0.7 & 40 & 7.2 & 3.3 & 42.5 & 0 & 2.1 & 4.2 \\
\hline AJ-74 & 55.3 & 43.6 & 1.1 & 42.8 & 8.4 & 4.1 & 37.9 & 0 & 0.8 & 4.9 \\
\hline AJ-76 & 62.2 & 35.8 & 2 & 35.3 & 22.1 & 4.8 & 25.6 & 0 & 4 & 6.2 \\
\hline AJ-78 & 44.7 & 55.3 & 0 & 29.7 & 10.9 & 4.1 & 50.8 & 0 & 1.1 & 3.4 \\
\hline AJ-81 & 33.5 & 62.6 & 3.9 & 19.7 & 10 & 3.8 & 59 & 0 & 3.6 & 0 \\
\hline AJ-83 & 52.7 & 45.1 & 2.2 & 34.1 & 13.4 & 5.2 & 39.9 & 0 & 2.1 & 3.1 \\
\hline AJ-85 & 30.2 & 69.8 & 0 & 20.6 & 7.2 & 2.4 & 62.3 & 0 & 3.9 & 3.6 \\
\hline AJ-87 & 39.5 & 60.5 & 0 & 24.7 & 7.9 & 6.9 & 55.5 & 0 & 1.6 & 3.4 \\
\hline AJ-89 & 52 & 46.4 & 1.6 & 43 & 7.8 & 1.2 & 42 & 0 & 2.3 & 2.1 \\
\hline AJ-91 & 35.6 & 62.6 & 1.8 & 14.3 & 13.2 & 8.1 & 54.5 & 0 & 3.8 & 4.3 \\
\hline AJ-92 & 36.3 & 58.8 & 4.9 & 24.3 & 8.4 & 3.6 & 52.8 & 0 & 2.1 & 3.9 \\
\hline AJ-93 & 54.9 & 40.5 & 4.6 & 37.9 & 11.7 & 5.3 & 36 & 0 & 2.3 & 2.2 \\
\hline AJ-94 & 30 & 68.2 & 1.8 & 17.8 & 5.5 & 6.7 & 62.5 & 0 & 1.6 & 4.1 \\
\hline AJ-97 & 31 & 68.1 & 0.9 & 14.8 & 12.9 & 3.3 & 60 & 0 & 3.2 & 4.9 \\
\hline AJ-98 & 31.8 & 68.2 & 0 & 9.8 & 17.1 & 4.9 & 60.5 & 0 & 2.2 & 5.5 \\
\hline AJ-99 & 36.1 & 62.8 & 1.1 & 15 & 16.8 & 4.3 & 56.3 & 0 & 3.4 & 3.1 \\
\hline AJ-100 & 42.3 & 55.7 & 2 & 26.5 & 10.3 & 5.5 & 50.1 & 0 & 3.2 & 2.4 \\
\hline AJ-102 & 53.7 & 43.4 & 2.9 & 33.3 & 17.7 & 2.7 & 39.1 & 0 & 1.4 & 2.9 \\
\hline AJ-103 & 37.4 & 62.6 & 0 & 12.8 & 20.8 & 3.8 & 58 & 0 & 2 & 2.6 \\
\hline AJ-104 & 58.6 & 39.5 & 1.9 & 38.9 & 14.5 & 5.2 & 36 & 0 & 0 & 3.5 \\
\hline AJ-105 & 48.3 & 50.6 & 1.1 & 27.8 & 16.5 & 4 & 45.5 & 0 & 1.5 & 3.6 \\
\hline AJ-106 & 33.1 & 65 & 1.9 & 24.1 & 6.3 & 2.7 & 57.9 & 0 & 3 & 4.1 \\
\hline AJ-107 & 50.9 & 45.3 & 3.8 & 33.6 & 11.8 & 5.5 & 40.6 & 0 & 2.3 & 2.4 \\
\hline AJ-108 & 46.6 & 50.6 & 2.8 & 32.5 & 10.6 & 3.5 & 45.1 & 0 & 1.5 & 4 \\
\hline AJ-109 & 32.3 & 65.7 & 2 & 20 & 6.6 & 5.7 & 57.3 & 0 & 3.2 & 5.2 \\
\hline AJ-110 & 34.4 & 65.6 & 0 & 21.6 & 11.8 & 1 & 59.3 & 0 & 2.9 & 3.4 \\
\hline AJ-111 & 32.9 & 64 & 3.1 & 22 & 8.9 & 2 & 57.3 & 0 & 3.1 & 3.6 \\
\hline AJ-112 & 49.6 & 48.9 & 1.5 & 40 & 7.1 & 2.5 & 43.1 & 0 & 2.9 & 2.9 \\
\hline AJ-113 & 33 & 63.9 & 3.1 & 20.6 & 7.8 & 4.6 & 56.9 & 0 & 2.2 & 4.8 \\
\hline AJ-114 & 60.9 & 34.1 & 5 & 44.6 & 10.5 & 5.8 & 26.8 & 0 & 1.2 & 6.1 \\
\hline AJ-116 & 44.1 & 52.8 & 3.1 & 27.5 & 8 & 8.6 & 46.3 & 0 & 3 & 3.5 \\
\hline AJ-117 & 88 & 11.1 & 0.9 & 47.5 & 32.3 & 8.2 & 8.2 & 0 & 0 & 2.9 \\
\hline AJ-118 & 84.5 & 13.3 & 2.2 & 46.1 & 22.6 & 15.8 & 11 & 0 & 0 & 2.3 \\
\hline AJ-119 & 45 & 54.4 & 0.6 & 28.6 & 12.2 & 4.2 & 47.4 & 0 & 3.3 & 3.7 \\
\hline AJ-121 & 37.9 & 61.5 & 0.6 & 22.4 & 9.9 & 5.6 & 54.5 & 0 & 3.5 & 3.5 \\
\hline AJ-122 & 40.8 & 58.1 & 1.1 & 19.9 & 17.6 & 3.3 & 50.9 & 0 & 3 & 4.2 \\
\hline AJ-127 & 39 & 60.3 & 0.7 & 16.2 & 17.7 & 5.1 & 56 & 0 & 1.5 & 2.8 \\
\hline AJ-128 & 38 & 60.5 & 1.5 & 19 & 11.6 & 7.4 & 53.6 & 0 & 3.6 & 3.3 \\
\hline
\end{tabular}




\begin{tabular}{ccccccccccc}
\hline AJ-129 & 34.7 & 63.4 & 1.9 & 22.7 & 8 & 4 & 56 & 0 & 2.8 & 4.6 \\
AJ-130 & 44.7 & 54.2 & 1.1 & 26.1 & 12.2 & 6.4 & 47.3 & 0 & 3.2 & 3.7 \\
AJ-131 & 31 & 66.5 & 2.5 & 24.4 & 4.1 & 2.5 & 56.6 & 0 & 4.1 & 5.8 \\
\hline
\end{tabular}

Note. Qt: total quartz; Lt: total lithic fragment; F: feldspar; Qu: undalatory monocrystalline quartz; Qnu: non-undalatory monocrystalline quartz; Qp: polycrystalline quartz; Ls: sedimentary lithic fragment; Lv: volcanic lithic fragment; Lm: metamorphic lithic fragment; Ch: chert.

The sandstone classification proposed by Folk [26] and Pettijohn et al. [27] has been followed in the present study. The modal analysis data were recalculated on a matrix-free basis and was plotted in the QFL diagram. Polycrystalline quartz, though not as durable as monocrystalline quartz, was placed at Q-pole to obviate the problems of distinction between plutonic polycrystalline quartz and metaquartzite fragments. In the triangular diagram constructed for delineating the tectonic setting of the provenance, polycrystalline quartz was placed at the RF pole (in the Lt pole of QmFLt plot of [3]). Chert was placed at the rock fragment pole as its origin can be unequivocally traced to a sedimentary source, though it was plotted at the Q-pole by several earlier workers [27, 28]. Chert is less stable than quartz during transport and placed the chert fragment at the RF-pole [26]. The F-pole comprises all types of feldspar grains.

For recognition of source rock lithology and tectonic setting of the provenance, the modal analysed data were plotted in the diamond diagram of Basu et al. [8] and Tortosa et al. [9], as well as QtFL and QmFLt triangular diagrams of Dickinson and Suczek [3].

\section{Detrital Framework Components}

The detrital framework grains of the Aghajari Formation sandstones include quartz, feldspars, rock fragments, and mica minerals such as biotite and muscovite. By studying the texture of these sandstone we observed that fine grains are angular, and coarser ones are rounded to broken rounded. This occurs because in a high-energy environment or through long-distance transport, the well-sorted, coarse-grained sands not only round completely, but also break to fine-grained, angular sands, which results in a decrease of the sediment sorting. Although chemical mechanisms can round the grains by corroding them, these mechanisms round the fine-grained sands more than the coarser ones (more exposed surface in fine-grained particles), which is not the case in this study. Therefore, the heterogeneous roundness of grains for different grain sizes in the Aghajari Formation sandstones reflect the importance of mechanical factors for the final grain shapes.

Quartz grain include two groups: monocrystalline quartz $(\mathrm{Qm})$ and polycrystalline quartz (Qp). Monocrystalline quartz $(\mathrm{Qm})$ occurs in two variants: non-undulose 
(4.1 to 32.3 with averaging $13.4 \%$ ) and undulose (9.8 to 62.2 with averaging $30 \%)[9,29,30]$. The polycrystalline quartz (Qp) (0.7 to 15.8 with averaging $4.5 \%)$ was distinguished into two groups: polycrystalline quartz with 2-3 subgrains (Fig. 2A) and polycrystalline quartz with more than 3 subgrains (Fig. 2B). Chert was considered as a monomineral [10] and was found only in a more samples (0 to 7 with averaging $4 \%$ ) (Fig. 2C). Some of the non-undulatory monocrystalline quartz contain inclusions (Fig. 2D). All studied thin sections contain small amounts of potassium feldspar (0 to 5 with averaging $1.7 \%$ ), including twinned microcline (Fig. 3A). Plagioclase occurs in some thin sections and seems to be linked to samples with smaller grain sizes (fine-grained sand) (Fig. 3B).
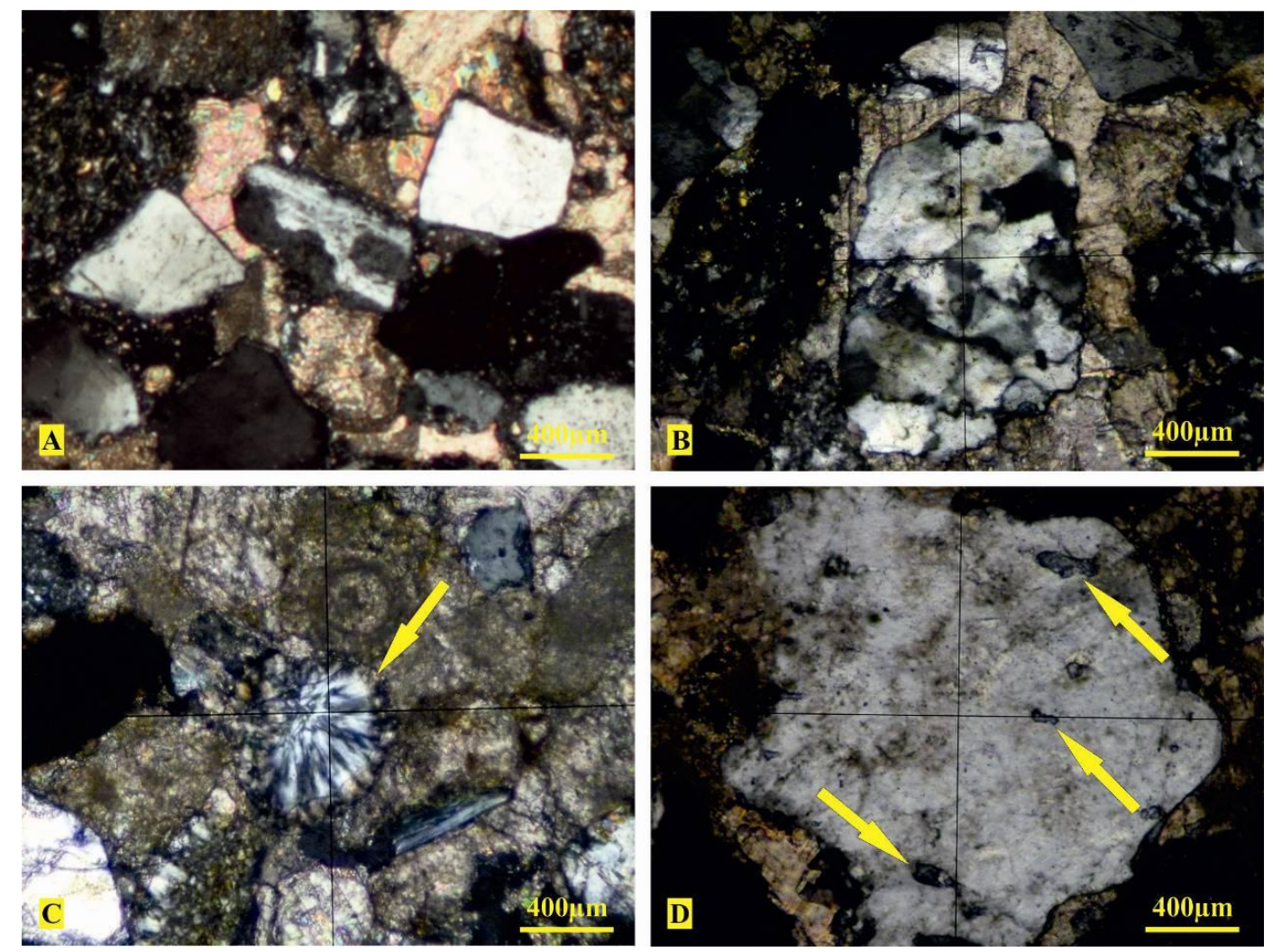

Fig. 2- Photomicrographs of sandstone samples of Aghajari Formation in XPL. A: polycrystalline quartz with 2-3 subgrains; B: polycrystalline quartz with more than 3 subgrains; C: chert grain; D: non-undulatory monocrystalline quartz contain inclusions.

Petrographic study of these sandstones reveals that K-feldspar is more abundant than plagioclase, which can be originated from durability of K-feldspars, nonoccurrence of plagioclase-bearing source rocks, or both. The feldspars are alter, which implies chemical weathering. 
A limited range of mica minerals was observed in thin section. The most common is biotite (Fig. 4A). Other mica mineral observed in thin-section was muscovite (Fig. 4B). The thin sections contain more amount of lithic fragments than quartz and feldspar grains. Lithic fragments found in the studied samples include: sedimentary fragments (5.1 to 64.3 with averaging $44.4 \%$ ) (siltstones (Fig. 5A), sandstones (Fig. 5B), and carbonate fragments (Fig. 5C)) and metamorphic fragments ( 0 to 4.1 with averaging $2 \%$ ). Volcanic fragments are absent in these sandstones. Metamorphic lithoclasts are usually made up of metamorphic polycrystalline quartz fragments of high-grade metamorphic origin. Typical source rocks for these lithoclasts would be gneisses [29]. Also, re-sedimented quartz grains with thin, rounded, syntaxial relictic rims of quartz cement (Fig. 5D) are common. Calcite occur in the well-cemented sandstone samples.
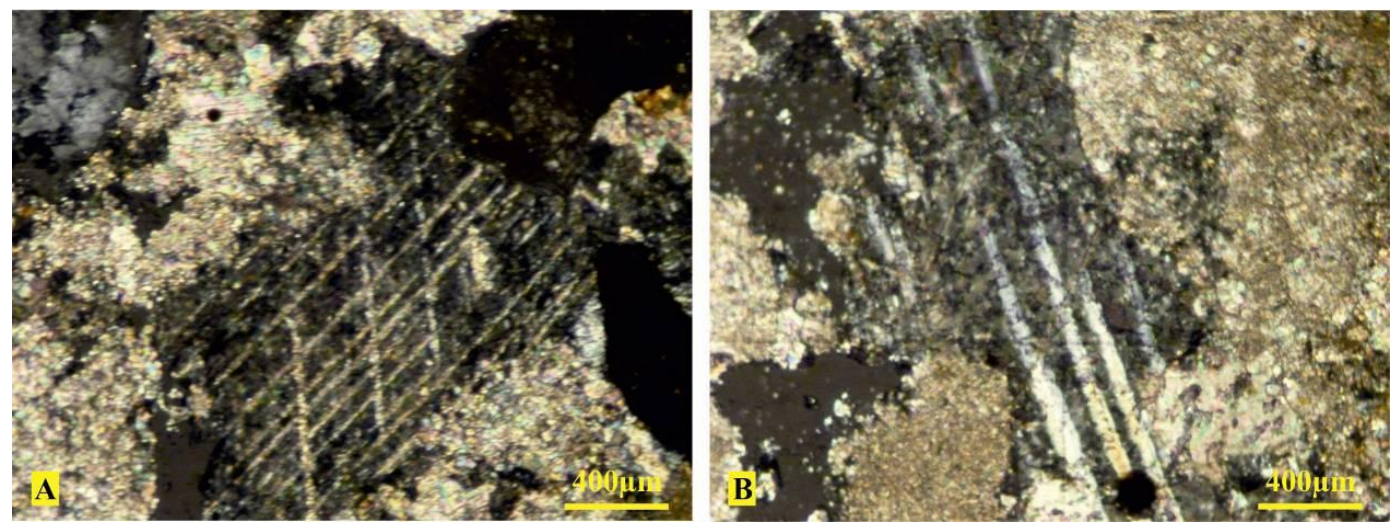

Fig. 3- Photomicrographs of feldspar grains in Aghajari sandstone in XPL. A: microcline grain; B: plagioclase grain.
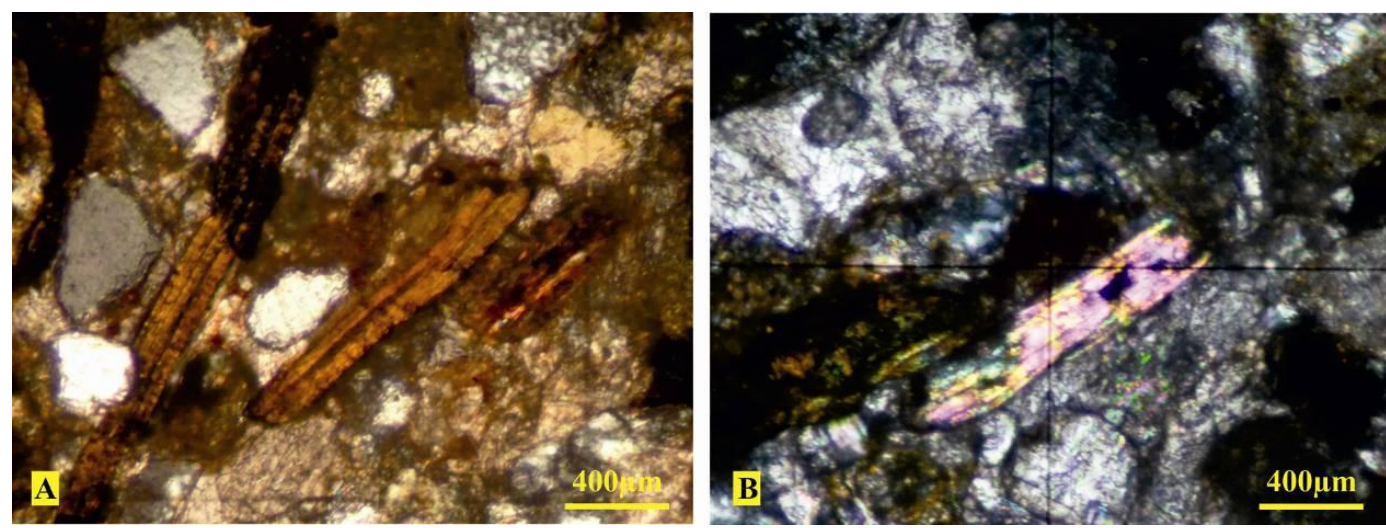

Fig. 4- Photomicrographs of mica grains in Aghajari sandstone in XPL. A: biotite grain; B: muscovite grain.

Using Folk [26] (Fig. 6A) and Pettijohn et al. [27] (Fig. 6B) classifications (QFL ternary plot), the Aghajari Formation sandstone samples were classified as lithic arenite and sublitharenite, thus reflecting their slightly mineralogical matured character (Fig. 7). 

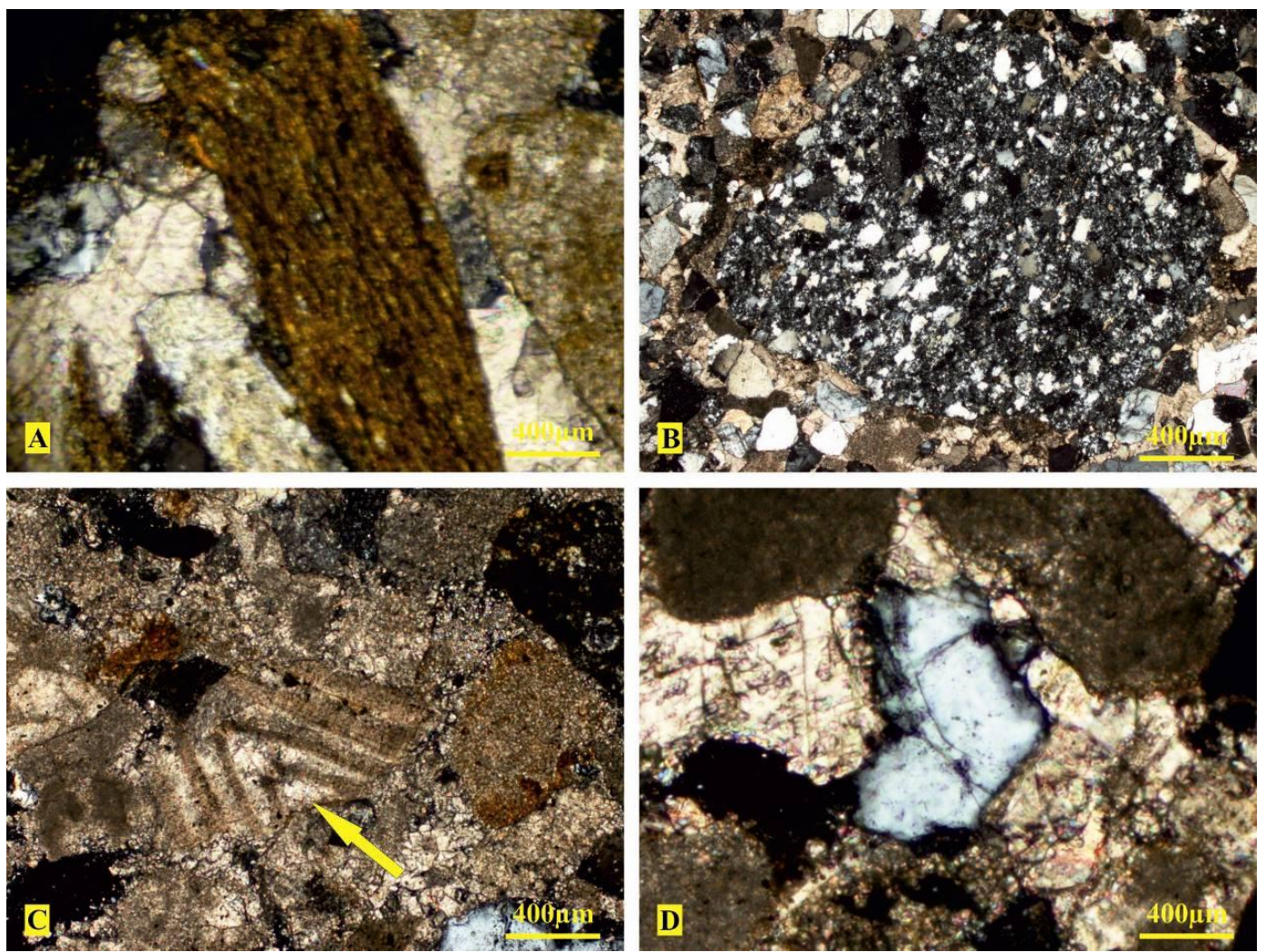

Fig. 5- Photomicrographs of Aghajari sandstone in XPL. A: siltstone lithic fragment; B: sandstone lithic fragment; C: carbonate lithic fragment; D: overgrowth quartz cement.
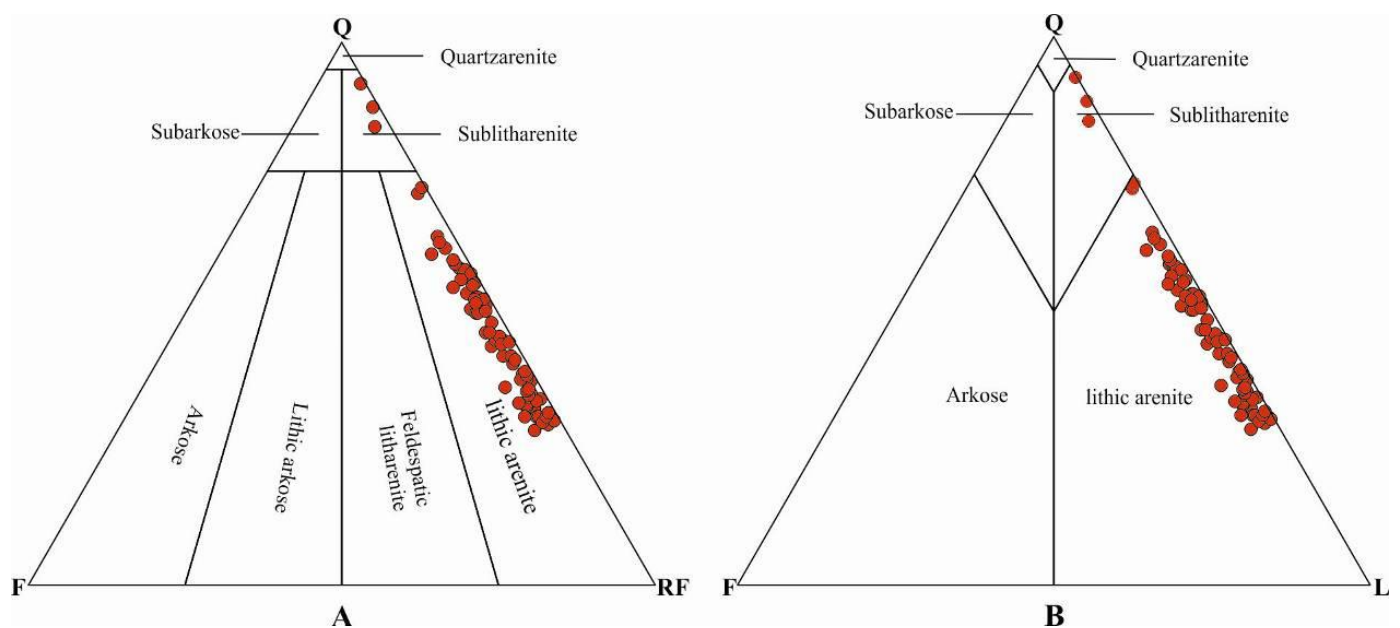

Fig. 6- Triangular classification plot of different sandstone samples from the Aghajari Formation. A: QFR triangular diagram (after ${ }^{[26]}$ ); B: QFL triangular diagram (after ${ }^{[27]}$ ). Q: quartz; F: feldspar; RF: rock fragment; L: lithic fragment. 


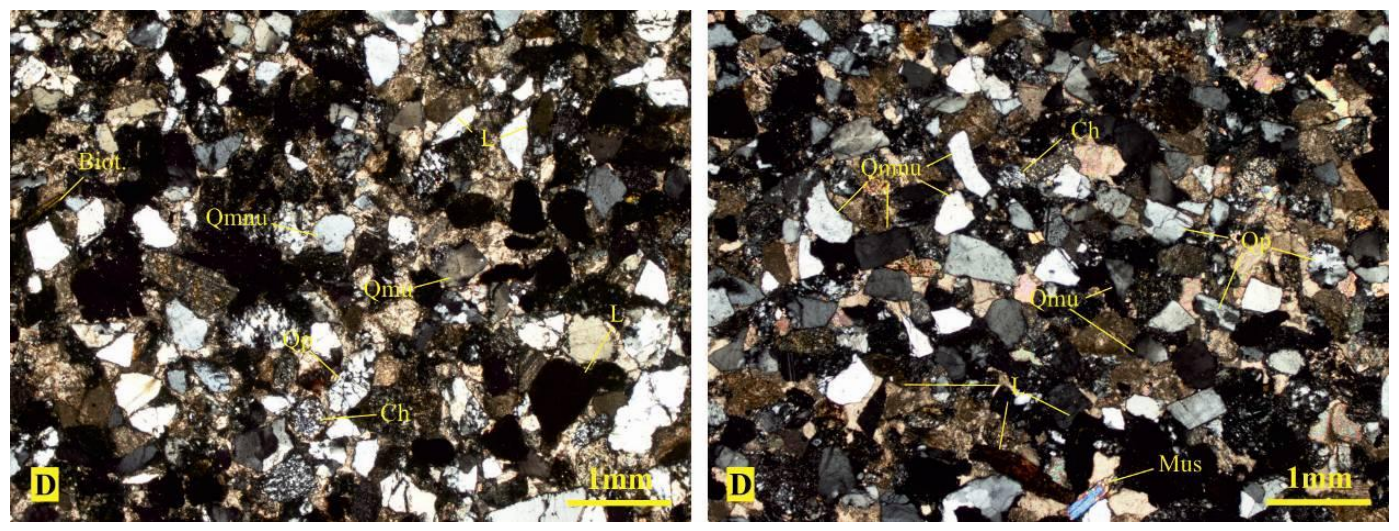

Fig. 7- photomicrograph of Aghajari Formation sandstones in XPL; A: lithic arenite; B: sublitharenite. Qp: polycrystalline quartz; Qmu: undulatory monocrystalline quartz; Qmnu: non-undulatory monocrystalline quartz; L: lithic fragment; Ch: chert grain; Biot: biotite; Mus: muscovite.

\section{Source Rock Lithology and Paleoclimate}

Petrographic evidence such as heterogeneous roundness for different grains (coarser ones are rounded and finer ones are angular) implies the importance of mechanical effects for grain shape configuration. Coarse-grained feldspars are related to a low degree of chemical weathering. Moreover, the rounded quartz overgrowths indicate recycling, which, in turn, can modify the compositional data towards the quartz-rich sandstones. Therefore, the petrographic evidence suggests that the compositional maturity of these sandstones may be due to recycling long transport on high-relief Arabian craton as has already been indicated by Ziegler [31] and may not be related to a humid climatic condition.

Petrographic analysis of the thin sections shows small percentages of polycrystalline quartz grains (Table 1), which are of polycrystalline quartz grains composed of more than five elongated crystals, exhibiting irregular to crenulated inter-crystal boundaries (Fig. 2B) that indicates an origin from metamorphic source rocks $[11,12]$. Moreover, the Aghajari Formation sandstones consists of monocrystalline quartz grains showing strong undulatory extinction and cryptopolycrystalline quartz grains, both suggestive of metamorphic source rocks.

To evaluate the relative importance of metamorphic rocks as quartz sources, we plotted polycrystalline quartz vs non-undulatory and undulatory monocrystalline quartz in a double-triangular diagram following the technique of Basu et al. [8] (Fig. 8A) and Tortosa et al. [9] (Fig. 8B). These approaches give dramatically different results; a high to low metamorphic origin, and a granitic/gneissic source rocks. These contrasting results can be partially explained by considering that the Aghajari Formation sandstone samples plot in a region of the diagram where only some of the granite sourced modern sands analyzed by Tortosa et al. [9] plot. 

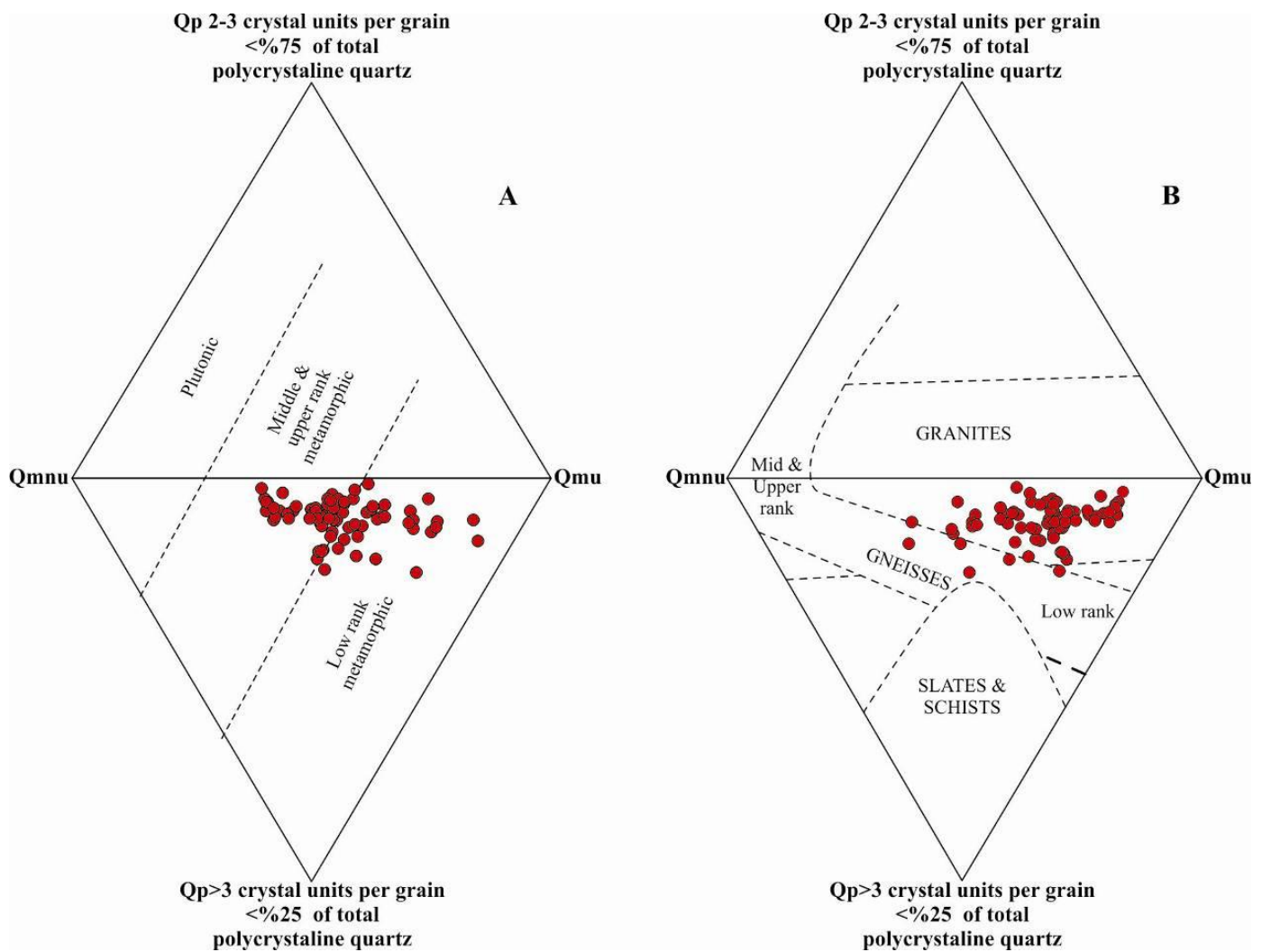

Fig. 8- Varietal quartz diamond plot currently used to discriminate sands sourced by different types of crystalline rocks, on the basis of the extinction pattern and polycrystallinity of quartz grains. Qmnu: non-undulatory monocrystalline quartz grains; Qmu = undulatory monocrystalline quartz grains; Qp2-3 = coarse-grained polycrystalline quartz grains; $\mathrm{Qp}>3$ = fine-grained polycrystalline quartz grains. Aghajari Formation sandstones are compared with provenance fields after Basu et al. [8] and Tortosa et al. [9] (diagrams A and B, respectively).

The effect of source rock on the composition of the Aghajari Formation sandstones could be distinguished by plotting the point count data on Suttner et al. [32] diagram (Fig. 9). This approach also point to a metamorphic source rock for these sandstones. The diagram of Suttner et al. [32] (Fig. 9), however, indicate a metamorphic source rock in a humid and arid climates. 


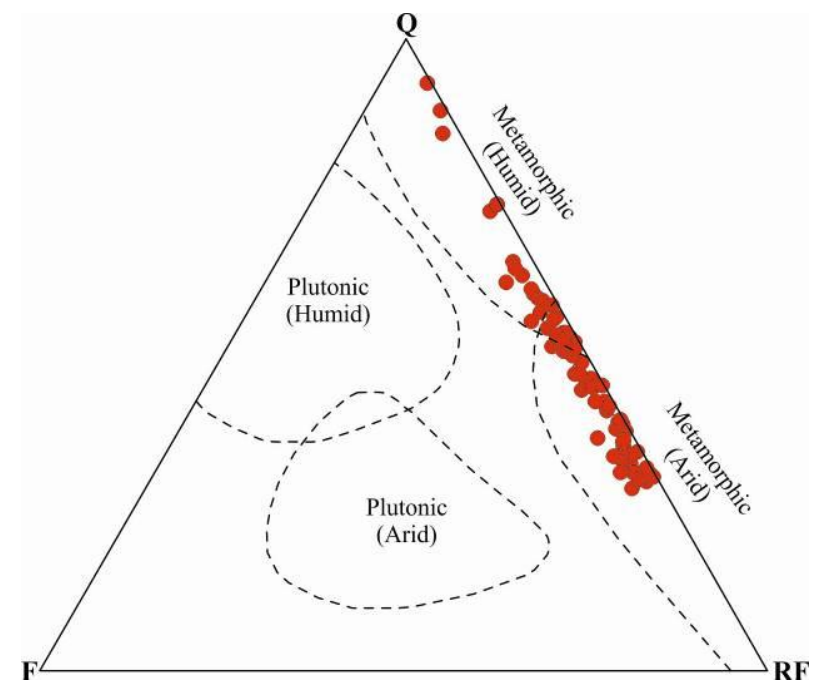

Fig. 9- The effect of source rock on the composition of the Aghajari Formation sandstone using Suttner et al. ${ }^{[32]}$ diagram. Q: Quartz; F: feldspar; RF: rock fragment.

\section{Provenance}

The main assumption behind sandstone provenance studies is that different tectonic settings contain characteristic rock types which, when eroded and produce sandstones with specific compositional ranges [7]. The analysis of sandstones with known provenance has been used to define these ranges from which the provenance of other samples can be deduced. Dickinson and coworkers have related detrital sandstone compositions to major provenance types such as stable cratons, basement uplifts, magmatic arcs and recycled orogens [3, 4]. In the QFL and QmFLt ternary diagrams of Dickinson et al. [4] the analyzed samples plot exclusively in the recycled orogen (quartzose and transitional recycled) field (Fig. 10). As pointed out by Dickinson et al. [4], sandstones plotting in this field are mature sandstones derived from relatively low-lying granitoid and gneissic sources, supplemented by recycled sands from associated platform or passive margin basins.

Crook [2] proposed the use of quartz content to infer tectonic setting, and linked quartz-rich (> 65\% quartz) sandstones to passive (Atlantictype) continental margins; intermediate quartz (15- 65\% quartz) sandstones to active (Andeantype) continental margins, and quartz poor $(<15 \%$ quartz) sandstones to magmatic island arcs. The quartz-rich (averaging $47.91 \%$ quartz) sandstones studied here thus correspond to the Andean- type sandstones of Crook [2]. 


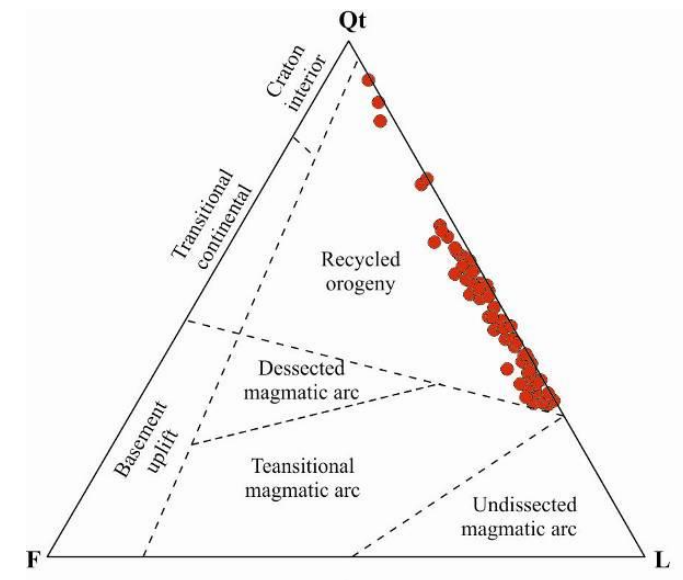

A

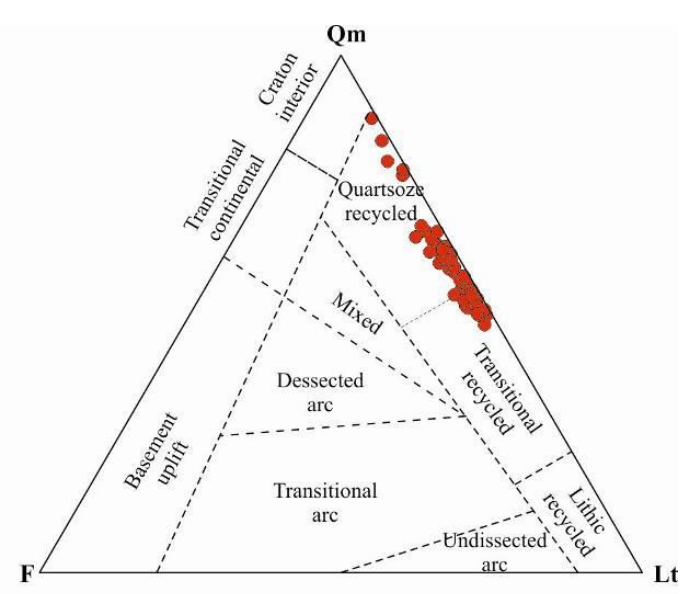

B

Fig. 10- Ternary diagrams for the Aghajari Formation sandstones, (after [4]). A: QtFL; B: QmFLt. Qt: total quartz grain; Qm: monocrystalline quartz; F: feldspar; L: lithic fragment; Lt: total lithic fragment.

\section{Conclusion}

Based on petrographical study of Aghajari Formation sandstones (in Folded Zagros Zone in southwestern Iran) two groups were identified: lithic arenites and sublitharenite. Provenance of these deposits are recycle orogen (quartzose and transitional recycled).

The quartz grains of the Aghajari sandstone are mainly derived from low and medium to high-grade metamorphic rocks. The relative dominance of polycrystalline quartz grains composed of $>3$ crystals $(\mathrm{Qp}>3)$ also proposes an origin from metamorphic source rocks. Similarly, the presence of mica indicate that the source area was composed of metamorphic rocks. However, the relatively greater abundance of monocrystalline quartz indicate that the presence of granitic and volcanic rocks in the source areas cannot be ruled out, or else the quartz grains have traveled a longer distance of transportation. Accordingly, the parent rocks of Aghajari Formation sandstones are granite/gneiss rocks.

Moreover, the obtained data are consistent with a long distance transport, in a variable climate, over the Arabian shield, which supplied these sands to their depositional basin along the passive margin of the Late Miocene-Pliocene Zagros foreland basin.

\section{Acknowledgements}

We thank the Islamic Azad University, Khorasgan (Esfahan) Branch and PayamE-Noor University of Shiraz for providing laboratory equipments. In addition, we are grateful to A. Heydarieh for his considerable help throughout this study. 


\section{References}

[1] Critelli, S., Le Pera, E., Ingersoll, R.V., "The effects of source lithology, transport, deposition and sampling scale on the composition of southern California sand", Sedimentology, Vol. 44, (1997), pp. 653- 671.

[2] Crook, K.A.W., Lithogenesis and tectonics: the significance of compositional variation in flysch arenites (greywackes), In: Dott, R.H., Shaver, R.H. (Eds), Modern and Ancient Geosynclinal Sedimentation, Special Publication 19, Society of Economic Geologists and Paleontologists, 1974, 304- 310.

[3] Dickinson, W.R., Suczek, C., "Plate tectonics and sandstone composition", AAPG Bulletin, Vol. 63, (1979), pp. 2164- 2182.

[4] Dickinson, W.R., Beard, L.S., Brakenridge, G.R., et al., "Provenance of North American Phanerozoic sandstones in relation to tectonic setting", Geological Society of American Bulletin, Vol. 94, (1983), pp. 222- 235.

[5] Weltje, G.J., "Quantitative analysis of detrital modes: statistically rigorous confi dence regions in ternary diagrams and their use in sedimentary petrology", Earth Science Review, Vol. 57, (2002), pp. 211- 253.

[6] Basu, A., A perspective on quantitative provenance analysis. In: Valloni, R., Basu, A. (Eds), Quantitative Provenance Studies in Italy, Memorie Descrittive Della Carta Geologica dell'Italia, Vol. 61, (2003), pp. 11- 22.

[7] Dickinson, W.R., Interpreting provenance relations from detrital modes of sandstones. In: Zuffa, G.G. (Ed), Provenance of arenites, Nato Advanced Study Institute Series, Reidel Publishing Company, 1985, pp. 333- 362.

[8] Basu, A., Young, S., Suttner, L., James, W., Mack, G., "Re-evaluation of the use of undulatory extinction and crystallinity in detrital quartz for provenance interpretation", Journal of Sedimentary Petrology, Vol. 45, (1975), pp. 873882.

[9] Tortosa, A., Palomares, M., Arribas, J., Quartz grain types in Holocene deposits from the Spanish Central System: some problems in provenance analysis, In: Morton, A.C., Todd, S.P., Haughton, P.D.W. (Eds), Developments in Sedimentary Provenance Studies, Geological Society of London, Special Publication, Vol. 57, (1991), pp. 47- 54.

[10] Folk, R.L., Petrology of Sedimentary Rocks, Hemphill Press, Austin, Texas, (1974).

[11] Blatt, H., Middleton, G., and Murray, R., Origin of Sedimentary Rocks, Prentice- Hall, Englewood Cliffs, NJ, (1980).

[12] Asiedu, D.K., Suzui, S., and Shibata, T., "Provenance of sandstones from the Lower Cretaceous Sasayama Group, inner zone of southwest Japan", Sedimentary Geology, Vol. 131, (2000), pp. 9- 24.

[13] Stocklin, J., Possible ancient continental margins in Iran, In: Burk, C.A., Drake, C.L. (Eds), The Geology of Continental Margins. New York, Springer, 1974, pp. 873- 887. 
[14] Berberian, M., King, G.C.P., "Towards the paleogeography and tectonic evolution of Iran", Canadian Journal of the Earth Sciences, Vol. 18, (1981), pp. 210- 265.

[15] Beydoun, Z.R., Hughes Clarke, M.W., Stoneley, R., "Petroleum in the Zagros basin: A Late Tertiary foreland basin overprinted onto the outer edge of a vast hydrocarbon- rich Palaeozoic- Mesozoic passive margin shelf", AAPG Bulletin, Vol. 55, (1992), pp. 309- 339.

[16] James, G.A., Wynd, J.G., "Stratigraphic nomenclature of Iranian oil consortium agreement Area", AAPG Bulletin, Vol. 49, No. 12, (1965), pp. 2182- 2245.

[17] Motiei, H., Stratigraphy of Zagros, Tehran, Geological Survey of Iran, (1993).

[18] Stocklin, J., Stratigraphic Lexicon of Iran, Geological Survey Of Iran, Report No. 18, 1977.

[19] Pollastro, R.M, Persits, F, Steinshouer, D., Map showing geology, oil and gas fields, and geological provinces of Iran, U.S. Geological Survey, Open-File Report 97-470G, 1999.

[20] Yousefi, T., 1:100000 map of Sarvestan, Tehran, Geological Survey of Iran, (2006).

[21] Al-Husseini, M.I., "Middle East Geological Timescale 2008", Journal of Middle East Petroleum and Geoscience, Vol. 13, No. 4, (2008).

[22] Bahrami, M., "Sedimentology and morphotectonical evolution of Aghajari and Bakhtiari Formations in north-western of Shiraz, Iran", Journal of Science, Islamic Azad University, Vol. 8, No. 27\&28, (1998), pp. 1995- 2010.

[23] Bahrami, M., "Lithofacies and Sedimentary Environments of Aghajari Formation in Dehsheikh Mountain, West of Shiraz, Iran”, World Applied Science Journal, Vol. 6, No. 4, (2009), pp. 464- 473.

[24] Sahraeyan, M., Bahrami, M., Hejazi, S.H., "Facies and sedimentary environments of Aghajari Formation in southeast of Sarvestan, Folded Zagros Zone, Iran", Proceedings of the conference of application of earth sciences in fundamental researchs of Iran, (2011), pp. 168- 175.

[25] Ingersoll, R.V., Bullard, T., Ford, R., Grimm, J., Pickle, J., Sares, S., "The effect of grain size on detrital modes: a test of the Gazzi Dickinson pointcounting method", Journal of Sedimentary Petrology, Vol. 54, (1984), pp. 103- 116.

[26] Folk, R.L., Petrology of Sedimentary Rocks, Hemphill Press, Austin, Texas, (1980).

[27] Pettijohn, F.J., Potter, P.E., Siever, R., Sand and Sandstone, second ed., Springer, New York, (1987).

[28] Blatt, H., "Provenance determination and recycling of sediments", Journal of Sedimentary Petrology, Vol. 37, (1967), pp. 1031- 1044.

[29] Scholle, P.A., A Color Illustrated Guide to Constituents, Textures, Cements, and Porosities of Sandstones and Associated Rocks: Tulsa, Oklahoma, American Association of Petroleum Geologists, Memoir, Vol. 28, (1979), 201p. 
[30] Basu, A., Influence of climate and relief on composition of sands released at source area, In: Zuffa, G.G. (Ed), Provenance of Arenites, Nato Advanced Study Institute Series, Reidel Publishing Company, Vol. 148, (1985), pp. 1-18.

[31] Ziegler, M.A., "Late Permian to Holocene paleofacies evolution of the Arabian plate and its hydrocarbon occurrences: Bahrain, Gulf Petrolink", Geo Arabia, Vol. 6, No. 3, (2001), pp. 445- 505. 